\title{
Opinion on the National Defense Education for College Students in the Context of MicroAge*
}

\author{
Lei $\mathrm{Li}$ \\ College of Information and Communication \\ National University of Defense Technology \\ Changsha, China \\ Ying Zhang \\ College of Information and Communication \\ National University of Defense Technology \\ Changsha, China
}

\author{
Bo Zhang \\ College of Information and Communication \\ National University of Defense Technology \\ Changsha, China \\ Yao Wu \\ College of Information and Communication \\ National University of Defense Technology \\ Changsha, China
}

\begin{abstract}
In the context of the development of MicroAge, the intensity of supervision over micro-platforms, the complexity of micro-platform information, and the impact of micro-platform on traditional national defense education classes have all brought challenges to traditional national defense education in colleges and universities.
\end{abstract}

Keywords-MicroAge; national defense education; college students

\section{INTRODUCTION}

With the rapid development of Internet technology, the network MicroAge is advancing irresistibly, and the development of micro-platforms has affected all aspects of social life. "It took 38 years for radio, 13 years for television, 4 years for the Internet, but only 14 months for Weibo to get one medium reach 50 million people" Li Kaifu once said. Traditional educational contents and methods are constantly being updated and replaced by high-speed information. The use of "MicroAge" instant communication media such as Weibo and WeChat has also brought new challenges to national defense education for college students.

National defense education is a nation's construction and efforts to uphold state sovereignty, territorial integrity and security, and to defend against foreign aggression and eliminate threats. College students are the key position of national defense education. Starting from higher education stage, where college students gradually improve their outlook on life and values, can further improve students' national defense thought, national defense knowledge, national defense skills and physical quality, thus laying a solid foundation for the country to train successors with high national defense awareness and quality. On the other hand, college students are quick at absorbing knowledge and accepting new things, which make them vulnerable to the influence of separatists with ulterior motives in society and even in the world. Lacking knowledge of national defense

\footnotetext{
*Fund: This paper is a phased achievement of SGH18H228 project.
}

will lead college students less capable of distinguishing right from wrong and thus lead them astray. Especially in the current age, the network environment is complex and micro platforms are widely applied, so college students' identification of network information and acceptance of micro-platform information under the influence of MicroAge should be the platforms for the state to strengthen national defense education.

\section{IMPACT OF IMPERFECT NETWORK SUPERVISION}

MECHANISM IN THE MicRoAgE ON NATIONAL DEFENSE EDUCATION FOR COLLEGE STUDENTS

According to the 43rd China Statistical Report on Internet Development issued on February 28, 2019, by December 2018, Internet users in China had reached 729 million and the Internet penetration rate had reached 59.6\%, 3.8 percentage points higher than the year before; the Internet users via mobile phones had reached 817 million. By December last year, China had 792 million instant messaging users, 675 million network news users, 612 million network video users and 648 million short video users. In the meantime, the number of college student netizens is increasing year by year. In addition to traditional classroom education, the channels for college students to acquire knowledge have been transferred to micro platforms. To regulate the network public opinion environment, China has issued a series of policy initiatives successively, such as the Notice of the People's Republic of China on Registration Form of International Networking Units, the Administrative Measures for the Security Protection of Computer Information Networks Linked to the Internet, the Network Security Management Regulations, and the Information Auditing Management Regulations, which play a positive guiding role in regulating network information. However, the fast and convenient communication mode of micro platforms is attracting college students who like new things, in addition to their weak ability to identify network information not conducive to national defense education, and insufficient regulation of the state and the colleges on network public 
opinion, so many college students feel overwhelmed by some overseas sensitive information and unpatriotic information, and get confused and disturbed to some extent. However, in this respect, colleges and universities have not established a corresponding supervision mechanism, nor they establish an accountability mechanism for the dissemination of bad information not conducive to national defense education. The reasons include three aspects. First, the information communication inspection system in colleges and universities is not well developed, it is difficult to use the "micro" platform in the national defense education, and the information regulation is also a heavy task. Therefore, it is difficult for colleges and universities to investigate the information communication supervision responsibility in the MicroAge. Second, to meet the needs of national defense education for college students in the MicroAge, colleges and universities post videos about patriotism and building China into a great power by WeChat Official Account, Weibo, Tik Tok and other platforms, which can achieve a certain effect, but cannot timely collect students' feedback, and adverse comments on such platforms are also out of the control by relevant supervision departments. Third, the colleges and universities do not have independent defense education micro platforms of their own, and they have been relying on social public platforms, which make it difficult to control the content and feedback. Only by establishing their own micro platforms of national defense education can they have the enthusiasm and initiative of the education. [1]

\section{IMPACT OF MULTIFARIOUS INFORMATION CONTENT ON NATIONAL DEFENSE EDUCATION FOR COLLEGE STUDENTS}

Information dissemination in the MicroAge is characterized by timeliness, extensiveness etc. The rapid and convenient information dissemination causes college students to rely on the "micro" platforms, through which they can obtain more knowledge and information. As a result, some college students even use their national defense education time to $\log$ on to WeChat, Weibo etc., which directly affects their academic performance and the promotion of national defense quality education. In the meantime, with the rapid development of Internet technology, the functions of smart phones are becoming increasingly powerful, and more and more college students own mobile phones, leading to rapidly increasing number of micro users. Information can be released freely through mobile phones, and information dissemination is characterized by openness and massification, which to a large extent satisfies the curiosity of college students. However, taking advantage of the not fully formed values of college students, some network communities or official accounts deliberately post some wrong ideas, news, novelty news and information that doesn't fit with core values and make false statements on the platforms to attract the attention of college students, cause concern and trigger discussion, so as to improve the notability of their platforms. Some college students mistakenly believe that public information can convey correct information, and some are not being able to fully distinguish between new, curious, and non-mainstream topics. Consequently, some college students are addicted to virtual social networks, gradually losing their understanding of real society and powerful country, resulting in serious lack of national defense knowledge and consciousness.

In the MicroAge, college students have more opportunities to participate in various hot events, and feel more independent to express their views, their participation becomes more diverse, and the participation environment has also changed. A large amount of bad information harmful to national security and stability has a direct impact on the quality of national defense education for college students. In the national defense education using "micro" platforms, it is hard to sift the information and some seditious information can be found on the micro platforms. Although domestic websites try to filter unpatriotic information, many college students who have overseas experience are able to log on some bad overseas websites and micro platforms to get some information or make some comments that are not conducive to national unity and development. Moreover, the national defense educators in colleges and universities of China cannot grasp such information accurately. Most national defense educators are not clear about the characteristics of the MicroAge, and there are still many defects in the collection, screening, selection and utilization of media information, which directly affects the effective development of national defense education for college students. From another perspective, this also puts forward higher requirements for the units and individuals engaging in national defense education. They should pay attention to students' discussion topics as well as their state of mind; make best use of the battle position - college classroom to lead students to establish correct national defense consciousness, absorb more national defense knowledge, and comprehensively improve their national defense quality; impart national defense knowledge to students not only through classroom, but also through second classrooms, club activities, campus culture etc. It is advisable to attach importance to national defense education and encourage college students to take the initiative to screen out unpatriotic information. [2]

In addition, national defense education for college teachers shall also be attached importance, so as to develop national defense education from the source. With weak national defense consciousness, some teachers believe that it is enough to perform well in their profession and technology, and tend to be xenocentric. As a result, they fail to impart or convey correct national defense knowledge, resulting in onesided national defense consciousness among students.

\section{DRAMATIC IMPACT OF LEARNING FORMS IN THE MicRoAgE on TRADITIONAL ClASSES OF NATIONAL DEFENSE EDUCATION FOR COLLEGE STUDENTS}

The traditional national defense education course in colleges and universities is mainly taught via the way of combining theory with practice. Military theory course is generally taught through special lectures and enlarged class, in which the teacher does not understand the degree of students' mastery of knowledge, let alone class interaction and individualized teaching. Military skill training of students remains on the surface level. The drillmasters help 
students develop good living habits, rigorous living style and spirit of unity and cooperation, but fail to raise citizens' awareness of crisis and national defense skills to the level of national defense construction, which defeats the purpose of military training. Some colleges do not offer military-related elective courses, so students do not have the access to their favorite courses. Many colleges and universities do not have their own full-time teachers of national defense theory, which will lead to an incomplete national defense education theoretical system. [3] Obviously, neither in form nor in content, the traditional national defense education cannot meet the needs of college students in the new era. Due to college students own shortcomings in addition to the inherent attraction of micro platforms to them, some students think they can play with mobile phones and get entertained in the national defense education class. In addition, some national defense education teachers do not combine the course with the new situation and new characteristics, and instead they still use the old-fashioned method, so national defense education in the most important position fails to achieve a satisfactory result.

\section{INTEGRATING INTO THE MICROAGE AND OPTIMIZING THE DEVELOPMENT OF NATIONAL DEFENSE CULTURE IN THE NEW ERA}

President Xi Jinping stressed that "a nation cannot rise and develop without spiritual strength; a career cannot last long without cultural support." In the face of the overwhelming MicroAge, it is necessary to develop national defense culture in a more active and flexible manner; make best of the convenient information of the MicroAge, rely on the strategic layout of building an all-round well-off society and the "five-sphere integrated plan"; integrate into the socialist core value system and highlight the problem orientation, characteristics of the Times and value functions of the national defense culture construction.

First, it is advisable to make full use of micro-culture and lead college students to integrate into the national defense culture of the whole society. The quality benefit of defense culture development first depends on the value orientation of the whole society. Therefore, colleges and universities should give full play to the high efficiency of micro-culture which lead college students to integrate with core value education, patriotism education, national security education, etc., and incorporate the national defense education into the national defense mobilization system construction and military-local cultural development layout to realize overall planning and scientific deployment. Second, it is necessary to form joint efforts for national defense culture development through military-local cooperation to establish and improve policies, laws, organizations, supervision, financial resources and other supporting measures for the development of national defense culture and form a pattern of mutual promotion and interaction between the military and the local and extensive participation of college students. It is also necessary to establish and improve national defense culture inspection, supervision, assessment and evaluation mechanisms, and promote the implementation of the work to achieve sound and sustainable development. Third, it is advisable to integrate the national defense culture development to the local national defense layout, make full use of national defense culture resources, implement key national defense culture projects, build quality cultural brands, actively explore national defense material and cultural resources, protect national defense historical sites, attach importance to maintenance of national defense facilities and equipment, and strengthen the construction of national defense education bases such as revolutionary sites, martyrs cemeteries and memorial venues.

Besides, it is advisable to use the powerful impact of micro culture and follow the principle of defense justice and benefits to raise social consciousness. Since ancient times, debate between justice and benefits has been a general proposition of the value orientation of Chinese traditional culture. The "utilitarianism" centered on benefit maximization and the one-sided thought only focusing on "economic benefit" but not considering political benefit, to varying degrees, have an impact on national defense culture among college students. It is necessary to fully use the powerful impact of micro culture, and combine thought guidance with benefit induction to raise the internal consciousness of social members to recognize and accept national defense culture, and enhance the realistic attraction of national defense culture to college students. To achieve this purpose, first, it is necessary to follow the law of cognitive development, strengthen the national defense identity of the whole people, and build a mnemonic community and an imagination community by comprehensively utilizing traditional national culture, national history and geography, national territorial sovereignty, mainstream ideology and national system, so as to strengthen the national identity of the whole people, including college students. Additionally, it is necessary to attach importance to establish the hardship image, threat early-warning and security expectation by using historical national defense disaster, realistic security threat, military strength comparison etc. to strengthen college students' recognition of national defense construction. It is necessary to, from China's future development, lead students to form an open and confident national mentality of a great power, and raise their "China consciousness" of China's all-round rise in economy, politics, military, culture and other aspects so as to strengthen college students recognition of China's military and national defense advancing to the world first class in the new era. It is also necessary to establish the inner value bond of college students, raise their national defense emotion, fully understand and respect the interest demands expressed by college students, help them balance national and social values with individual and family values, unite the individual career development of them with the need of national security, so as to promote the positive reinforcement of their national defense emotion with the positive correlation between individual interests and national interests.

\section{CONCLUSION}

The development of the MicroAge is the inevitable outcome of the development of information technology to a new stage, and the new era has endowed national defense 
education with more important meaning and mission. The research on the challenge to traditional national defense education in the context of the MicroAge aims to find a solution to the gap in the actual work, absorb what is best and discard the dregs, and make the best use of the advantages of the MicroAge, so as to effectively develop national defense education for college students.

\section{REFERENCES}

[1] Luo Xiong. The Study of National Defense Education of Contemporary College Students under the Background of Chinese Dream [J]. Journal of Hubei Correspondence University, Volume 28, Issue 5, NO.147. (in Chinese)

[2] Sun Dayong. Constructing a New Path of Ideological and Political Education for College Students by Using Weibo [J]. Journal of Jining Medical University, 2014 (6): 430-432. (in Chinese)

[3] Yin Chenxi. Research on the Innovation of Ideological and Political Education for College Students in the "MicroAge" [J]. Industrial Technology and Vocational Education, 2014 (3): 64-66. (in Chinese) 